\title{
Exploratory Analysis of Differences between Social Experience Design and User Experience Design
}

\author{
Toshihiko Yamakami Software Solution, ACCESS \\ Nakase 1-10-2, Mihama-ku, Chiba-shi \\ Chiba, Japan 261-0023 \\ Email: Toshihiko.Yamakami@access-company.com
}

\begin{abstract}
User experience design brought with it a new framework for computer and human interaction. It focused on the total user experience, and not the case-by-case on alternative user interfaces. The natural extension of this concept in connection with emerging social services leads to social experience design. In order to formulate the basis on which social experience design stands, the author performs an exploratory analysis of the differences between social experience design and user experience design. This comparison is a starting point for formulating a study of social experience design.
\end{abstract}

Keywords-Social experience, user experience, social serivces, service engineering, experience design

\section{INTRODUCTION}

Since the Internet has facilitated social networking services, it is important to develop a socially-invoked user experience. Social experience has multiple unique characteristics that are not observed in user experience. With the increasing stay time of social services on the Internet, worldwide, it is crucial to develop a systematic methodology for social experience design, the social version of user experience.

The term "user experience" has brought about a departure from the functional aspect of user interaction. User interaction is a human experience that is tightly bound to the human emotional aspect. This is also true when user experience is extended to social experience, which is user experience in a social context.

Extending of user experience to social contexts is challenging. The definition of social experience design is still immature. Research into social experience design has a long way to go. It involves the multiple obstacles based by research studies that deal with social contexts. Exploring experiences in social contexts is open-ended; therefore, it is necessary to define the scope of exploration first.

The author discusses the design of social experience using a comparison of social experience and user experience.

\section{BACKGROUND}

\section{A. Purpose of Research}

The aim of this research is to identify differences between social experience design and user experience design.

\section{B. Related Works}

The term "User Experience" has been influencing user interaction design for two decades with its departure from the computer-human interface toward high-level interaction design. It was coined by Donald Norman in the 1990's. Norman also presented the concept of user-centered system design [1]. He approached usability from the viewpoint of cognitive psychology [2]. Buxton has been another visionary in user experience design since the 1990's. He discussed the design innovation from the viewpoint of user experience design [3].

Norman also discussed emotional design and mentioned that emotion is an essential part of life, affecting how we feel, how we behave and how we think [4]. He argued that usability and pleasure should go hand in hand.

Human beings are social creatures. Their emotions and pleasures are closely bound to social contexts. As social services emerge, the need for designing social contexts is increasing. It is natural that user experience should be extended to cover social experience.

Social user experience (social UX) is attracting research attentions. Väänänen-Vainio-Mattila et al discussed the main drivers of social UX including self-expression, reciprocity, learning and curiosity [5]. Vermeeren et al. discussed UX evaluation methodologies through literature review and other approaches. One of their findings was the need for developing methods for social and collaborative UX evaluation [6]. Tuch et al. discussed narratives in UX and showed that positive narratives predominantly concern social aspects such as family and friends [7].

Yamakami used the metaphor of user experience design in social contexts and proposed the concept of social experience design [8]. He examined social experience design using evolution-path-based analysis [9].

In the early literature, social systems represented organizational systems. The social aspects of information technology research were organization-focused. An organization is an open system [10]. Grudin presented eight challenges to groupware that stem from social dynamics [11]. Those challenges were complicated, tacit, and difficult to deal with, which has not changed much up to today.

The originality of this paper lies in its identification of differences between social experience design and user experi- 
TABLE I

EXAMPLES OF HIDDEN AND SUBTLE RELATIONSHIPS IN MOBILE SOCIAL GAME DESIGN

\begin{tabular}{|l|l|}
\hline Example & Description \\
\hline Self-exposure & $\begin{array}{l}\text { Social recognition is important even when other } \\
\text { members do not pay any serious attention to it. The } \\
\text { expectation of social recognition influences behavior } \\
\text { and satisfaction. }\end{array}$ \\
\hline Expectation & $\begin{array}{l}\text { Each member's expectations in social contexts are } \\
\text { diverse and asymmetric. These expectations matter } \\
\text { even more than the actual occurrence of social inter- } \\
\text { action. }\end{array}$ \\
\hline $\begin{array}{l}\text { Discontinuous } \\
\text { social context }\end{array}$ & $\begin{array}{l}\text { In most social games, a large part of the game is } \\
\text { consumed in solo-play because social interactions } \\
\text { can be stressful. Alternating cycles of low social } \\
\text { contexts and high social contexts are important in } \\
\text { social game design. }\end{array}$ \\
\hline Tacit trust & $\begin{array}{l}\text { Trust is tacit. Any attempts to bolster or revive trust } \\
\text { may have counter-effects. }\end{array}$ \\
\hline
\end{tabular}

ence design in order to highlight the research scope of social experience design.

\section{Social EXPERIENCE Design}

\section{A. Definitions}

The fundamental research question for social experience design is "What is social experience design?" And, the best approach to this question is "What are the differences between social experience design and user experience design?" The author attempts to explore this second question in this paper.

The following acronyms are used in this paper:

- UX: User Experience

- UXD: User Experience Design

- SX: Social Experience

- SXD: Social Experience Design

\section{B. Example: Hidden relationships in mobile social game design}

The author conducted an analysis of social game design throughout 2011 and 2012. During this period of analysis, it became clear to the author that the simple addition of SX to UX would create further discrepancies in total experience design. This is partly because there are many cases where the influence of SX on UX is hidden and subtle. Examples of some such hidden and subtle relationships are depicted in Table I.

These tacit implications of SX on UX make defining the border between SX and UX a challenge.

\section{Research Questions}

A breakdown of the relevant questions is depicted in Table II.

This list of research questions is not exhaustive. These questions serve to increase awareness of the long road ahead that challenges research and the goal of developing best practices for SX design. They highlight the difficulty of identifying the boundary between SX and UX, as well as the boundary between SX design and UX design. In this paper, the author examines multiple factors that define the boundary between SX and UX, and the boundary between SX design and UX
TABLE II

RESEARCH QUESTIONS

\begin{tabular}{|l|l|}
\hline Breakdown & Description \\
\hline Definition & $\begin{array}{l}\text { What is the difference between the definition of UX } \\
\text { and the definition of SX? }\end{array}$ \\
\hline Scope & $\begin{array}{l}\text { What is the difference in scope between SXD and } \\
\text { UXD? }\end{array}$ \\
\hline Evaluation & What metrics used in SXD are different from UXD? \\
\hline Principles & $\begin{array}{l}\text { What principles used in SXD are different from UXD } \\
? \text { (One of the major principles of UXD is user- } \\
\text { centered design) }\end{array}$ \\
\hline $\begin{array}{l}\text { Evaluation } \\
\text { environment } \\
\text { (methodologies) }\end{array}$ & $\begin{array}{l}\text { What evaluation environments (methodologies) used } \\
\text { in SXD are different from UXD? }\end{array}$ \\
\hline Goal & What goals pursued in SXD are different from UXD? \\
\hline Time frame & $\begin{array}{l}\text { Is there a difference in time frames between SXD } \\
\text { and UXD? }\end{array}$ \\
\hline User-perception & $\begin{array}{l}\text { What is the difference between user-perceived SX } \\
\text { and user-perceived UX? }\end{array}$ \\
\hline $\begin{array}{l}\text { Values of experi- } \\
\text { ence }\end{array}$ & $\begin{array}{l}\text { Is there an explicit difference in the values of expe- } \\
\text { rience between SX and UX? }\end{array}$ \\
\hline Relationship & $\begin{array}{l}\text { Is there overlap between SXD and UXD? Does some } \\
\text { part of SXD include UXD internally? }\end{array}$ \\
\hline
\end{tabular}

TABLE III

EXAMPLES OF CONFLICT BETWEEN SX AND UX

\begin{tabular}{|l|l|}
\hline Example & Description \\
\hline $\begin{array}{l}\text { UX efficiency } \\
\text { and quality of }\end{array}$ & $\begin{array}{l}\text { Efficiency of operations may harm the quality of } \\
\text { SX because of operational asynchrony and because } \\
\text { efficiency does not always harmonize with social } \\
\text { satisfaction. }\end{array}$ \\
\hline $\begin{array}{l}\text { UX usability and } \\
\text { quality of SX }\end{array}$ & $\begin{array}{l}\text { Usability may harm the quality of SX because some } \\
\text { part of usability comes from aligning efforts on the } \\
\text { other human end. }\end{array}$ \\
\hline $\begin{array}{l}\text { UX discrepancies } \\
\text { from interference } \\
\text { of other members }\end{array}$ & $\begin{array}{l}\text { Improvement of one user's UX may impede another } \\
\text { user's UX due to asynchrony, inequality of burdens, } \\
\text { roles, and responsibilities. }\end{array}$ \\
\hline
\end{tabular}

design. This difference analysis provides clues to defining these boundaries and provides the building blocks of design methodologies for dealing with the interactions between SX and UX.

\section{Differential ANALysis of Social Experience DESIGN AND USER EXPERIENCE DESIGN}

UX involves the concept of creating a new architecture or an interaction model that will impact user perception of a valued experience. UXD involves a design that focuses on UX in order to elicit a positive attitude or response toward a service/product. One of the major principles of UXD is usercentered design.

"Social" can refer to the multi-faceted features of human beings. The author mainly addresses multi-user interpersonal aspects in this paper.

From this viewpoint, the difference between SX and UX is the difference between socially-invoked experience and nonsocially-invoked experience.

The basic hypothesis of this paper is that SX is a subset of UX. However, the complicated nature of SX can lead to conflicts between SX and UX. Examples of conflict between SX and UX are depicted in Table III.

These conflicts show that the combination of SX and UX requires overall management guidelines that can deal with both of SX and UX. 
TABLE IV

CASES WHERE SX IS NOT A COLLECTION OF UX

\begin{tabular}{|l|l|}
\hline Example & Description \\
\hline $\begin{array}{l}\text { Social } \\
\text { satisfaction }\end{array}$ & $\begin{array}{l}\text { Members have different roles and role-related levels } \\
\text { of satisfaction. Each level of satisfaction may be } \\
\text { designed in a separate manner and with a separate } \\
\text { mechanism. }\end{array}$ \\
\hline $\begin{array}{l}\text { Rewards for en- } \\
\text { gagement }\end{array}$ & $\begin{array}{l}\text { Rewards for social engagement may be different even } \\
\text { though the final outcome is an aggregated social } \\
\text { engagement. }\end{array}$ \\
\hline $\begin{array}{l}\text { We-ness enforce- } \\
\text { ment }\end{array}$ & $\begin{array}{l}\text { How members feel we-ness depends on their skills, } \\
\text { experiences, and expectations. All these factors may } \\
\text { be designed in separate functions. }\end{array}$ \\
\hline Locus of control & $\begin{array}{l}\text { High locus of control in social contexts may place } \\
\text { burdens and stresses on other users. }\end{array}$ \\
\hline Social stress & $\begin{array}{l}\text { Too much visibility of social activities may impede } \\
\text { each user's UX. }\end{array}$ \\
\hline
\end{tabular}

TABLE V

UNIQUE CHARACTERISTICS OF SX DESIGN

\begin{tabular}{|c|c|}
\hline $\begin{array}{l}\text { Unique } \\
\text { characteristics }\end{array}$ & Description \\
\hline Asynchrony & $\begin{array}{l}\text { Human response is not necessarily synchronous with } \\
\text { its original elicitation. }\end{array}$ \\
\hline Complexity & $\begin{array}{l}\text { Social emotion is leveraged by multiple aspects of } \\
\text { human interactions. }\end{array}$ \\
\hline Long-term-ness & $\begin{array}{l}\text { Social emotion sometimes forms over a long span of } \\
\text { time. }\end{array}$ \\
\hline $\begin{array}{l}\text { Collective feed- } \\
\text { back }\end{array}$ & $\begin{array}{l}\text { Emotion is built up from multiple different interac- } \\
\text { tions with different persons. }\end{array}$ \\
\hline Open-ended-ness & $\begin{array}{l}\text { Social emotion is impacted by events outside of } \\
\text { a service. There is no single, concrete, uniform } \\
\text { goal in SX. The members are not fixed in many } \\
\text { social systems, which involve constant changes and } \\
\text { dynamics. }\end{array}$ \\
\hline Unpredictability & Social interactions are unpredictable. \\
\hline Implicitness & $\begin{array}{l}\text { People sometimes cannot explicitly describe how } \\
\text { they feel in a social context. }\end{array}$ \\
\hline $\begin{array}{l}\text { No single end- } \\
\text { point }\end{array}$ & $\begin{array}{l}\text { Different members feel differently. It is difficult to } \\
\text { coin a single end-point of social experience. }\end{array}$ \\
\hline $\begin{array}{l}\text { Multiple } \\
\text { meanings }\end{array}$ & $\begin{array}{l}\text { A social experience may have multiple different } \\
\text { meanings for each of the members. }\end{array}$ \\
\hline $\begin{array}{l}\text { Delicate arbitra- } \\
\text { tion }\end{array}$ & $\begin{array}{l}\text { Social experience may require balance, compro- } \\
\text { mises, give-and-take in order to establish a stable } \\
\text { point. These social tunings are difficult to analyze. }\end{array}$ \\
\hline $\begin{array}{l}\text { High impacts on } \\
\text { user engagement }\end{array}$ & $\begin{array}{l}\text { Social interaction provides some strong building } \\
\text { blocks of user engagement in a service due to the } \\
\text { personal need for self-recognition, human built-in } \\
\text { reciprocity, and pleasure from positive social expe- } \\
\text { rience. }\end{array}$ \\
\hline
\end{tabular}

It should be noted that a collection of superior UXs do not equate to a superior SX. Examples are depicted in Table IV.

These conflicts demonstrate the necessity of identifying management guidelines that can deal with conflicting domains.

SX design has some unique characteristics compared to UX. The unique characteristics of SXD are depicted in Table V.

These characteristics indicate that SX is not only complicated, but also tacit and dynamic, and covers a long span of time without a simple and finite goal.

The advantages of designing better SX are depicted in Table VI.

Among them, the biggest advantage of SX lies in its impacts on the engagement of a service. High engagement leads to predictability, ease of conversion (including purchase), and high satisfaction for a user. Many services leverage this aspect in order to secure user engagement. Many gamification
TABLE VI

ADVANTAGES OF DESIGNING BETTER SX

\begin{tabular}{|l|l|}
\hline Advantages & Description \\
\hline User satisfaction & $\begin{array}{l}\text { Human beings have a social existence. Good social } \\
\text { relationships through good social experiences pro- } \\
\text { vide the basic building blocks of user satisfaction. }\end{array}$ \\
\hline Engagement & $\begin{array}{l}\text { Good social relationships bring a forward momentum } \\
\text { step toward strong social engagement that facilitates } \\
\text { regular use of a service. }\end{array}$ \\
\hline Social persuasion & $\begin{array}{l}\text { When there is uncertainty, social persuasion works } \\
\text { well. A good social relationship harnesses a service's } \\
\text { capacity for social persuasion. }\end{array}$ \\
\hline $\begin{array}{l}\text { Social-tie } \\
\text { resilience }\end{array}$ & $\begin{array}{l}\text { Strong social engagement endows a service with } \\
\text { resilient capabilities. When there is exceptional in- } \\
\text { habitability in a service, good social experience } \\
\text { facilitates a positive attitude toward a service. }\end{array}$ \\
\hline
\end{tabular}

TABLE VII

DIFFERENCES OF SX AND UX

\begin{tabular}{|c|c|c|}
\hline & SX & UX \\
\hline Domain & $\begin{array}{l}\text { Socially-invoked } \\
\text { experience }\end{array}$ & $\begin{array}{l}\text { Non-socially invoked expe- } \\
\text { rience }\end{array}$ \\
\hline Interaction & $\begin{array}{l}\text { Interpersonal } \begin{array}{l}\text { interactions } \\
\text { (help, } \\
\text { greeting, ... }) \text {. }\end{array}\end{array}$ & $\begin{array}{l}\text { Human-machine } \\
\text { interaction (operation } \\
\text { on a machine or device). }\end{array}$ \\
\hline Usability & $\begin{array}{l}\text { Usability of interpersonal } \\
\text { interactions. }\end{array}$ & $\begin{array}{l}\text { Usability of single-user op- } \\
\text { erations. }\end{array}$ \\
\hline Learnability & $\begin{array}{l}\text { Learnability of operations } \\
\text { of social interactions. }\end{array}$ & $\begin{array}{l}\text { Learnability of single-user } \\
\text { operations. }\end{array}$ \\
\hline Efficiency & $\begin{array}{l}\text { Efficiency of social interac- } \\
\text { tions. }\end{array}$ & $\begin{array}{l}\text { Efficiency of single-user } \\
\text { operations. }\end{array}$ \\
\hline Emotion & $\begin{array}{l}\text { Social emotion (we-ness, } \\
\text { revenge, happiness of be- } \\
\text { ing acknowledged, ...). }\end{array}$ & $\begin{array}{l}\text { Single-user emotion (hap- } \\
\text { piness, comfortableness, } \\
\ldots \text {... }\end{array}$ \\
\hline Cognition & $\begin{array}{l}\text { Cognition of members' ac- } \\
\text { tivities. Cognition of being } \\
\text { acknowledged. }\end{array}$ & $\begin{array}{l}\text { Cognition of single-user } \\
\text { service status. }\end{array}$ \\
\hline Feedback & $\begin{array}{lr}\text { Interpersonal } & \text { feedback } \\
\text { (positive } & \text { human } \\
\text { responses). } & \\
\end{array}$ & Feedback from a service. \\
\hline Commitment & $\begin{array}{l}\text { Socially-empowered com- } \\
\text { mitment (social engage- } \\
\text { ment). }\end{array}$ & $\begin{array}{l}\text { Single-user commitment } \\
\text { (positive attitude toward a } \\
\text { service). }\end{array}$ \\
\hline Expectation & Expectation of others & Expectation of service \\
\hline Trust & Trust in others & Trust in service \\
\hline $\begin{array}{l}\text { Time } \\
\text { dimension }\end{array}$ & $\begin{array}{l}\text { Sometimes Long-term and } \\
\text { asynchronous }\end{array}$ & Mostly synchronous \\
\hline $\begin{array}{l}\text { Representa- } \\
\text { tiveness }\end{array}$ & $\begin{array}{l}\text { There is no single repre- } \\
\text { sentative case to define so- } \\
\text { cial interactions. }\end{array}$ & $\begin{array}{l}\text { Representativeness in } \\
\text { human-machine interaction } \\
\text { is larger compared to the } \\
\text { social interaction. }\end{array}$ \\
\hline Tacit-ness & $\begin{array}{l}\text { Many interpersonal feel- } \\
\text { ings, emotions, relation- } \\
\text { ships, and ties are tacit. }\end{array}$ & $\begin{array}{l}\text { The interaction between a } \\
\text { system and a human be- } \\
\text { ing is explicit at the point } \\
\text { of human-machine interac- } \\
\text { tion. }\end{array}$ \\
\hline
\end{tabular}

techniques of engagement include social factors, such as social cognition and competition.

The differences between SX and UX are depicted in Table VII.

They include design component aspects, methodological aspects, and emotional and cognitive aspects. The combination of these factors, and interplay between them, lead to difficulties in dealing with SX.

The metrics for evaluating SX are depicted in Table VIII. The choice of metrics depends on the priorities among SX and UX requirements. It should be noted that social artifacts are intangible and difficult to deal with. 
TABLE VIII

METRICS FOR EVALUATING SX

\begin{tabular}{|l|l|l|}
\hline Aspect & Metric & Description \\
\hline UX & Efficiency & $\begin{array}{l}\text { Efficiency metrics such as time to complete a } \\
\text { social task. }\end{array}$ \\
\cline { 2 - 3 } & Satisfaction & $\begin{array}{l}\text { Human feelings of satisfaction, such as a user } \\
\text { survey using Lickert scales. }\end{array}$ \\
\hline SX & Social fits & $\begin{array}{l}\text { Fits to real-world social relationships. Comfort } \\
\text { of continuing social relationship. }\end{array}$ \\
\cline { 2 - 3 } & Social stress & Stress that users feel during operation. \\
\cline { 2 - 3 } & $\begin{array}{l}\text { Social } \\
\text { engagement }\end{array}$ & $\begin{array}{l}\text { Social engagement that is delivered during oper- } \\
\text { ations. }\end{array}$ \\
\cline { 2 - 3 } & Social ties & Quality of social ties among members. \\
\cline { 2 - 3 } & $\begin{array}{l}\text { Being } \\
\text { rewarded }\end{array}$ & $\begin{array}{l}\text { Strength of sense of being rewarded in social } \\
\text { relationships. }\end{array}$ \\
\hline
\end{tabular}

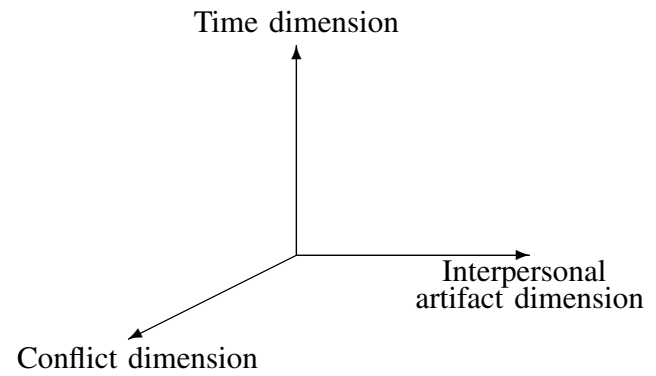

Fig. 1. A 3-dimensional view model of uniqueness of social experience

\section{Two View Models of SX Characteristics}

A 3-dimensional view model of social experience design is depicted in Fig. 1.

The first dimension, the interpersonal artifact dimension, covers visible and invisible interpersonal artifacts. It includes concrete shared objects, and invisible artifacts such as shared emotion, commitments in social contexts, reciprocity, shared norms, social ties, working culture, and tacit knowledge of a group. It is unique to SX because these visible and invisible artifacts are deliverables of social interaction.

The second dimension, the time dimension, covers the longterm-ness that deals with social trust, norms, relationships, and expectations. It also covers goals and deliverables under a long span of time. UX has to deal with a long-term dimension, however, many invaluable components of social relationships rely on continuity, consistency, and validation over a span of time. This dimension also deals with asynchrony and autonomy in social experience. Social experience deals with open-endedness, which is related to a long time dimension.

The third dimension, the conflict dimension, covers mismatches among users, including emotion, expectations, burdens, interests, and culture. It also covers diversity, heterogeneity, asymmetry of relationship, and dynamism.

These are the dimensions that are unique, therefore, any future design methodology that integrate SX and UX needs to address them.

The author examined the best practices of mobile social game design and came to recognize that not only are some SX-unique, but also some SX implicitly impact UX. These

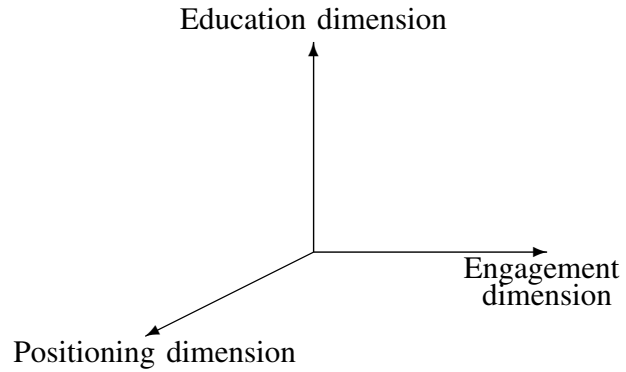

Fig. 2. A 3-dimensional view model of SX factors impacting UX

are subtler compared to the unique characteristics of SX stated above. However, the integrated design methodology needs to address these aspects in a sufficient manner.

The three impacting factors are depicted in Fig. 2.

The first dimension, the engagement dimension, deals with happiness, joy of use, encouragement, and commitment. The positive attitude toward a service is heavily impacted by social interaction and sensing the attitudes of other members. This is an important design factor involving social services.

The second dimension, the education dimension, deals with knowledge sharing of usage, guidance, and exploration of services. Social knowledge impacts UX, encouragement toward initiating use, and expectation. Expectations during education have a strong impact on social services. In many mobile Internet services, a large-scale mass of beginners provides an advantages for hot services with a consistent mass of users with a high tendency of followers.

The third dimension, the positioning dimension, deals with the user perspective of a service both in the relationship between a user and a service, and the relationships among users. Attention and viewpoint plays an important role not only in social relationships, but also in single-user experience. Different levels of attention and viewpoints provide a different landscape for UX.

These SX impacts on UX represent an unexplored fields that compensates existing UX.

\section{DISCUSSION}

\section{A. Advantages of the proposed approach}

The concept of user experience has provided a rich influence on human-machine interaction that surpasses the short-sighted optimization of user interfaces.

As the social interaction is addressed more and more by the Internet services, the need for capturing user experience involving multiple users is increasing. The rise of mobile social games indicates that social contexts are important not just for the fundamentally-social tasks, but also a crucial key for improving user engagement of services in a general manner.

The most straight-forward way is to combine of singleuser UX and multi-user UX. As the author examined the 
building blocks of social game design, he became aware of the complexity of UX and SX in social game design.

Considering the increasing need for social services and applications in social contexts, it is necessary to examine the social experience and to identify building blocks for an integrated methodology. Also, it is important to pay attention to social factors when improving user engagement, which is crucial for service engineering.

The findings and view models provide a basis for creating checklists, design patterns, and the best practices that cover the social aspect of user experience.

\section{B. Limitations}

This research is a qualitative study. The quantitative measures for identifying and verifying many of the aspects of social experience design discussed in this paper remain for further study.

Quantitative analysis of performance and user satisfaction of social experience design requires future research.

The concrete design methodology of social experience design is beyond the scope of this paper.

Many research questions stated in the early section of this paper still remains challenges for research.

\section{CONCLUSION}

The need for social service design is emerging as many Internet services start to feature socially engaged functionality. Facebook is a massive success with its 1.1 billion monthly active users, as of June 2013.

The two factors, increasing social services and the human need for pleasure in social contexts, are driving the importance of social service design. As a natural extension of user experience design to social experience, social experience design is a hot new field of research.

As the author explored the design patterns of social experience design, he came to recognize the uniqueness of social experience design. In this paper, he performed a difference analysis of social experience design and user experience design. The differences highlight the research challenges that face SX design.

The author proposes two view models of the characteristics of SX. The first model serves as to highlight the challenges of SX, which contrasts with the unique characteristics of SX. The second model highlights the feedback of SX upon UX, which explores the implicit relationships from SX to UX.
These models provide a stepping stone toward future integrated design methodologies that combine SX and UX in a seamless manner.

This research serves as a checklist for validating future SX design patterns and design methodologies.

\section{REFERENCES}

[1] D. Norman and S. W. Draper, User Centered System Design. Hillsdale, NJ, U.S.A.: Lawrence Erlbaum Associates, 1986.

[2] D. Norman, The Psychology of Everyday Things. New York: Basic Books, 1988.

[3] B. Buxton, Sketching User Experiences: Getting the Design Right and the Right Design (Interactive Technologies). New York: Morgan Kaufmann, 2007.

[4] D. A. Norman, "Emotional design," Ubiquity, vol. 2004, no. January, pp. 1-1, Jan. 2004.

[5] K. Väänänen-Vainio-Mattila, M. Wäljas, J. Ojala, and K. Segerståhl, "Identifying drivers and hindrances of social user experience in web services," in Proceedings of the SIGCHI Conference on Human Factors in Computing Systems, ser. CHI '10. New York, NY, USA: ACM, 2010, pp. 2499-2502.

[6] A. P. O. S. Vermeeren, E. L.-C. Law, V. Roto, M. Obrist, J. Hoonhout, and K. Väänänen-Vainio-Mattila, "User experience evaluation methods: current state and development needs," in Proceedings of the 6th Nordic Conference on Human-Computer Interaction: Extending Boundaries, ser. NordiCHI '10. New York, NY, USA: ACM, 2010, pp. 521-530.

[7] A. N. Tuch, R. Trusell, and K. Hornbæk, "Analyzing users' narratives to understand experience with interactive products," in Proceedings of the SIGCHI Conference on Human Factors in Computing Systems, ser. CHI '13. New York, NY, USA: ACM, 2013, pp. 2079-2088.

[8] T. Yamakami, "From user experience to social experience: A new perspective for mobile social game design," in UFirst 2012. IEEE CS, September 2012, pp. 792-796.

[9] _ "An evolutionary path-based analysis of social experience design," in $M U E-2013$, vol. LNEE 240. Springer Verlag, May 2013, pp. 69-76.

[10] C. Hewitt, "Offices are open systems," ACM Transactions on Information Systems, vol. 4, no. 3, pp. 271-287, July 1986.

[11] J. Grudin, "Groupware and social dynamics: eight challenges for developers," CACM, vol. 37, no. 1, pp. 92-105, 1994.

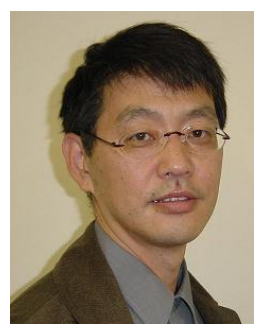

Toshihiko Yamakami received the B.E.I.S. and M.S.I.S. from University of Tokyo, Japan, in 1982 and 1984 respectively. He received the Ph.D. degree in reliability information system engineering from Kagawa University, Japan, in 2007. He was engaged in International standardization of systems in the application layer and mobile Webs in ISO, W3C, and WAP(OMA). His research interests include service engineering, gamification, and organizational knowledge and change management. He is a Senior specialist at ACCESS, Japan. He has been a member of the ACM since 1982, and is its life-time member. He obtained the IPSJ Yamashita Award in 1995. He published 150 international conference papers. 